\title{
The Implementation of Village Fund Allocation (ADD) In Banyuwangi : Case Study In Pesanggaran District
}

\author{
Nur Soetjiati \\ Head of the Other Regional Tax Billing subsection, Regional Revenue Office of Banyuwangi Regency \\ nur.suciatil23@yahoo.com
}

\begin{abstract}
The village funds allocation given by the government of Banyuwangi Regency to the villages in the Pesanggaran sub-district is an effort to motivate the village in financing the activities of the Village Government. The purpose of this study is to describe, explain and analyze the accountability system in the management of Village Fund Allocation in the District Pesanggaran Banyuwangi. This research uses field research method which gives description about Accountability of Village Fund Allocation Funding in Pesanggaran District of Banyuwangi Regency. Data collection techniques using observation, interview and documentation techniques, by selecting informants who play a vital role and are involved technically and functionally in Accountability Management of Village Fund Allocation. The data that has been obtained then analyzed using qualitative research method. The results of this study are: (l). Village Fund Allocation Planning in Pesanggaran Sub-District, first discussed in the village development plan, involves the community in decision-making and to determine the development to be implemented in the village located in Pesanggaran sub-district. (2). Implementation of the Village Fund Allocation, implemented transparently, local villagers were given access to know the use of the village funding allocation fund. For example, from the activities carried out in installing information boards of ongoing projects / activities such as writing what activities are ongoing, how much funding is used, how long the implementation of the duties, and who the executor. (3). Accountability in the implementation of the allocation of village funds should be done as a form of village government accountability in managing funds obtained from the government.
\end{abstract}

Keywords : Accountability, Village Fund Allocation

\section{INTRODUCTION}

Based on Law No. 32/2004 concerning Regional Government, it has been regulated regarding the implementation of a decentralized system in the country of Indonesia, where the central government gives greater authority to the regions to carry out a series of processes, mechanisms and planning stages that can guarantee the harmony of development (Thomas, 2013). authority to the Village Government based on Law number 32 of 2004 concerning Regional Government as amended twice with Law number 12 of 2008, has implications for increasing the obligations of the Village Government which must be implemented as a manifestation of efforts to meet the needs of the community.

The enactment of Law Number 6 of 2014 concerning Villages (Village Law), has positive implications because the village then has the autonomy to regulate and manage its own affairs. With the existence of this village autonomy, the administration of government must be independent, that is, from, and for the people, which automatically brings with it impacts related to village obligations and responsibilities. The practice of 
decentralization in the implementation of village autonomy must prioritize the principles or principles of Good Governance (good governance) to manage public resources owned, both concerning fiscal accountability, managerial and program.

One element of the principles of Good Governance is good element of accountability or accountability. Accountability as a form of government responsibility to the community for various management and implementation of governance in the village. One form of governance in the village is specifically related to village financial management. As Sumaryadi (2016: 18) explained that the principle of accountability was born as an obligation of the government to account for all actions and activities, especially in the area of financial administration to those who gave the task in this matter were the people who gave sovereignty to the government.

Banyuwangi Regency as one of the autonomous regions in the administrative region of East Java Province is trying to realize the principles of good governance in village financial management to help and realize participatory village government. The granting of ADD to villages that has been carried out by the Banyuwangi District Government is based on several levels of local regulation including Regional Regulation Number 02 of 2006 in conjunction with Regional Regulation Number 02 of 2007 concerning Village Fund Allocation and Regent Regulation Number 20 of 2013 concerning Implementation Guidelines and Technical Guidelines for Regional Regulations Number 02 of 2007 concerning ADD. In the regulation stated that the purpose of providing ADD assistance to villages from the Banyuwangi Regency government was as a stimulus in funding the Village Government's Empowerment and Empowerment program activities.

Based on the Banyuwangi Regency Regulation Number 2 of 2006 concerning Village Fund Allocation which has been amended by the Banyuwangi Regency Regulation Number 2 of 2007, it is explained that in the implementation of the Village Budget and Expenditure (APBDesa) all village expenditure is carried out through village treasury supported by evidence of expenditure legitimate. For this reason, the Village Treasurer must keep records of all village revenues and expenditures, using the Government Accounting System (SAP).

The selection of the object of this research was conducted in Pesanggaran subdistrict, one of the sub-districts located farthest from the capital of the Banyuwangi patent, referring to the Inspection Report Results of the Banyuwangi Regency regarding financial management in 5 (five) villages in the Pesanggaran subdistrict, especially regarding ADD management it was reported that: not fully in accordance with the stipulated provisions. Thus researchers are interested in conducting research on the accountability of Village Fund Allocation management in 2014, with a focus on the application of the principles of accountability carried out by the Village Implementation Team covering the planning, implementation and accountability stages. Because the researchers consider that this phenomenon needs to be studied and analyzed how the actual management of ADD at the implementation level in the field. 


\section{METHODOLOGY}

The design of this study is a qualitative research with a descriptive analysis approach. The researcher uses a qualitatives approach to describe hostically the research subject, so that it can describe the focus of the research, which is to answer the problems that have been formulated and meet the research objectives. This Research focus on Implementation of ADD in Pesanggaran District.

As for the primary data sources of researchers in this study are:

a. Village Government as the Village Implementation Team (Village Head, Secretary and Treasurer)

b. The Village Community Empowerment Institute (LPMD) as the Physical Development Activity Implementation Team, is represented by the chairman and members who are competent in the management of ADD

In addition to obtaining data relating to supervision, the selected informants were District Head (Camat), the District Secretary (Sekcam), the Head of the Village Community Empowerment Section, the Head of the Government Section and elements of the Village Consultative Body (BPD). While secondary data is data that has been processed in the form of written texts or documents, for example in the form of decrees, regional regulations, regent regulations and so on.

Data collection techniques carried out by researchers include:

a. Interview

Interviews with stakeholders in the policy process are identified and interviewed. A small number of key informants are assumed to be very influential in ADD management

b. Documentation

At this stage requires the process of identification, collection of material and related data and analysis of policy documents in the form of: (1). ADD management documents; (2). Meeting documents and technical meetings between the Village Head and LPMD and BPD

c. Observation

Observation techniques that are carried out either directly or indirectly or formally or informally are used to observe various activities. This is done in order to complete the primary data in the field and secondary data that have been collected previously.

The procedure for data analysis, are:

l. Organize the whole data that have been collected through the interview, documentation and observation.

2. Analyze the data by read it attenticely and make marginal notes for the important information, the encode the data.

3. Finding and classifying statements felt by respondents by doing horizontalonal ie every statement that is not relevant to the topic and questions or statements that are repetitive or overlapping are eliminated 
4. Reducing data, sorting out, centralizing, and simplifying the data that has just been obtained from raw research that emerged from written records in the field.

5. Presentation of data, namely by compiling and compiling information in the form of a single unit, selective and easy to understand.

6. The formulation in the conclusion, namely by conducting a review in the field to test the truth and validity of the meaning that appears there. The results obtained are presented, then presented in a narrative form

To obtain degree of trust, researchers undertake:

1. Extend the observation period

2. Continuous observation;

3. Triangulation;

4. Discuss it with others (peer debrieving), namely with academics in Banyuwangi.

5. Analyze negative cases;

6. Using reference material;

7.Researchers used tape recordings and other documentation material.

8. Hold "Membercheck"

\section{RESULTS AND DISCUSSION}

A. Result

The Village Fund Allocation accountability system in Pesanggaran subdistrict is intended to realize good governance, which according to Haryanto (2007: 10) states that the principles or rules ofgood governance represent participation, transparency and accountability in the implementation of government and development. Haryanto's intention certainly includes villages in the Pesanggaran subdistrict. Regarding the implementation of ADD accountability, of course there are stages that must be carried out. The phases begin with planning, implementation, and ending with accountability. The rules are stated in Regent Regulation No. 20 in 2013 and the Regional Regulations of Banyuwangi Regency Number 2 of 2006 as amended by the Regional Regulations of Banyuwangi Number 2 of 2007. To strengthen the narrative above the researcher interviewed the Sekcam Pesanggaran, in essence he stated that:

"The community has now been given the opportunity to participate in planning, implementation and evaluation in the implementation of development, for example they were involved in musrenbangdes." ( Results of an interview with Sekcam Pesanggaran, on April 23, 2015)

In line with the Sekcam Pesanggaran, the researcher also obtained a statement from the Head of the Village Community Empowerment Section, which stated that:

"In carrying out Village Fund Allocation activities, we always refer to the Regent's Regulation number 20 of 2013 regarding Implementation 
Guidelines and ADD technical guidelines." (Interview, with the Village

Community Empowerment Section Head, April 23, 2015).

The statements of the two informants above can be analyzed that the participatory application of rural community development is carried out transparently, accountably and responsively in the implementation of ADD. This means that this is in accordance with the opinion of an expert named Tjokroamidjojo (2000: 78) states that the involvement of every citizen in making decisions both directly and through the institutions that represent them. Therefore in this study discussed the planning, implementation and evaluation in management village funds allocation for villages in the Pesanggaran subdistrict.

"All village funds are disbursed from the APBDes and the program is the entire program of the ADD budget with a note attached with support, of course there are notes, receipts and if there is a proposal using a report and there is a final report." (Results of an interview with treasurer Sumbermulyo, on April 23, 2015)

The results of these interviews indicate that during the ADD implementation, it is reported that progress in the implementation of activities by the ADD manager at the village level, especially regarding physical activities and fund absorption. Thus it can be seen that the responsibilities of the ADD manager at the village level have fulfilled the provision for a gradual ADD activity final report on activities. The accountability of the ADD program to the upper levels of the government is carried out through a periodic reporting system. The ADD implementation report consists of a preliminary report, a report on each phase of the activity, a monthly report, and a final report of the activities compiled comprehensively.

Meanwhile, every three months the Village Head through the evaluation forum is responsible for the implementation of ADD to the community. The information is known from a Head of Kandangan Village who said:

"I have to be responsible every 3 months to the community through a joint forum with BPD" . ( Interview, Head of Kandangan Village, April 23, 2015).

The statement was strengthened by the Head of Pesanggaran Village who gave the following statement to researchers:

"In answering to the community I have to be transparent , meaning I have to explain in detail about the implementation of ADD." ( Interview, Head of Pesanggaran village on April 23, 2015).

In addition to the evaluation of the ADD program implementation, it is also a means of education for the community, how to actively participate, for example, participate in opinions or make corrections in the ADD implementation. The village government is also enthusiastic about receiving input from the community so that it is expected to be more perfect in the implementation of ADD. If examined closely in terms 
of accountability, the villages in the pesanggaran sub-district in the ADD implementation have largely fulfilled the accountability theory as conveyed by Tjokroamidjojo (2000: 75), namely the accountability of the management / organization carried out.

In each meeting or meeting the implementation accountability is described by the village head physically or administratively to the community in accordance with supervision by the community through the BPD. Submission of reports is carried out through structural channels, namely from the Village Level Implementation Team and is known by the Village Head to the District Level Support Team in stages.

The supervision of ADD management in Pesanggaran subdistrict has been going well, according to what the informant said:

"The form of supervision in this case from the sub-district there is guidance and there is also a companion to oversee the activities of the Regional Representative Council. In the village sector we follow the instructions or procedures of the ADD implementation where the implementation was carried out by the ADD Implementation Team. " (Results of interview with the Head of Sumberagung village, on April 27, 2015)

This statement is supported by the following acknowledgment from an informant from the Head of Pesanggaran village:

"Supervision is carried out every Monday and Thursday down to the villages to coordinate related to ADD, which conducts coaching, namely the government and the sekcam under the auspices of the district head. Schedule by invitation, sometimes twice a month. "(Results of interview with Head of Pesanggaran Village, 23 April 2015)

Besides that, the statement is also reinforced by the results of the interview as follows:

"In the sub-district there is an ADD co-ordinating team from the planning stage to be in accordance with the ADD implementation guidelines. From the planning stage, we are accompanied, it is hoped that there will be no mistakes during the ADD implementation. If there is a potential violation, we will be given guidance or reprimand to improve the implementation. And if the SPJ is incomplete, we have range and guidance so as to minimize the error rate. " Secretary of Sumbermulyo, on April 23, 2015)

\section{B. Discussion}

In the Planning Stage, it is preceded by a village development planning meeting (Musrenbangdes) involving the LPMD BPD and other community leaders subsequently based on the results of the musrenbangdes. The Village Head Prepares a Village Regulation Draft on the Village Medium Term Development Plan (RPJMDes) to discuss together with the BPD. 
In the implementation of Village Fund Allocation Activities carried out transparently, meaning that the community in the local village is given access to find out the use of the ADD funds. For example, from the activities carried out, put up an information board of projects / activities that are going on, for example, containing writing of what activities are taking place, how much funds are used, how long the implementation of these activities, the village community means that the process is carried out in a transparent manner. honest and non-discriminatory about the management of village finances in each of the stages both in planning and budgeting the implementation of the accountability budget and the results of examinations while still paying attention to the protection of the personal rights of groups and village secrets. Determine that every activity and the final outcome of village governance activities, especially village financial management, must be held accountable to the community.

Accountability in the implementation of village fun allocations must be done as a form of accountability of the village government in managing funds obtained from the government. The evaluation of the ADD program implementation also guides the community to actively participate in providing input and corrections by collaborating with village officials, treasurers, and the Village Fund Allocation Implementation Team so that ADD reporting can be completed quickly and appropriately. It is known that the ADD implementation has understood and understood about ADD financial administration governance because there are always instructions from the district government.

Supervision of ADD funds and the implementation of activities is carried out in a functional, embedded and operational manner by the Banyuwangi District Inspectorate, the ADD Assistance Team, and carried out by the community through the BPD. The success of ADD management is measured by increasing community knowledge about ADD, increasing community participation in village level development planning consultations, and increasing community knowledge about the accountability of village government using ADD.

The success of using ADD is measured by:

1. Funded activities in accordance with those planned in the APBDes;

2. Financial absorption (realization) in accordance with the target;

3. High employment rate;

4. The large number of beneficiaries, especially from poor families;

5. The high contribution of the community in supporting the use of ADD;

6. An increase in Original Village Income;

7. Able to work together with government programs in the village

Supervision of the various existing indicators, it can be said that the management of ADD in Pesanggaran subdistrict has been successful. Indicators that have been fulfilled in Pesanggaran subdistrict include easy access to the community to the center of economic and government activities, increasingly even services in the field of government, the formation of a Village Implementation Team, the formation of community initiatives in managing and being responsible for the sustainability of the 
use of built infrastructure, increasing community participation and the level of absorption of local work in the village development program .

From the results of the aforementioned research it can be summarized that the accountability of the management of the Village Fund Allocation in the District of Pesanggaran has been based on the principle of transparency and the principle of accountability. Thus it is necessary to make improvements on an ongoing basis while still adjusting the situation and conditions and the development of applicable laws and regulations.

\section{CONCLUSION}

The villages in the Pesanggaran subdistrict in managing the allocation of village funds are as follows:

1. Village Fund Allocation Planning in Pesanggaran subdistrict is first discussed in village development deliberations, involving the community in making decisions and to determine the development that will be implemented in villages in the District Budget.

2. Implementation of Village Fund Allocation, carried out transparently, the community in the local village is given access to find out the use of the ADD funds. For example, from the activities carried out, put up an information board of projects / activities that are taking place, for example, containing writing what activities are taking place, how much funds are used, how long the implementation of these activities, and who is implementing them.

3. Accountability in the implementation of Village Fund Allocation both technically and administratively is good, but must still get or be given guidance from the sub-district government as a form of accountability of the village government in managing funds obtained from the government. Because in reality, after an inspection by the Banyuwangi Regency Regional Inspector, there were several findings in the ADD Accountability in 5 (five) Villages in the Pesanggaran subdistrict in accordance with the Comprehensive Inspectoral Report of the Banyuwangi Regency Region on April 8, 2015

\section{REFERENCES}

Alwasilah, A. C. (2002). Pokoknya Kualitatif : Dasar-Dasar Merancang dan Melakukan Penelitian Kualitatif. Jakarta: Pustaka Jaya.

Bogdan, R. C. And Steven J. T. (1992). Introduction to Qualitative Research Method, Boston: John Wiley \& Sons.

Casmidi (2004). Ketimpangan Fiscal Horizontal dan Formula Dana Alokasi Desa DAD)", (Tesis S-2 Sekolah Pascasarjana UGM (tidak dipublikasikan). 
Creswell, J. W. (2014). Research Design: Qualitative and Qualitative Approaches, Thousand Oaks, California: Sage Publications.

Culla, A. S. (2002). Masyarakat Madani, Pemikiran, Teori dan Relevansinya Dengan Cita-cita Demokrasi. Jakarta : Raja Grafindo Persada.

Dede, R. dkk. (2000). Demokrasi, Hak Asasi Manusia Dan Masyarakat Madani. Jakarta: ICCE UIN Syarif Hidayatullah.

Dwipayana, A. S. E. (2003). Membangun Good Governance di Desa. Yogyakarta : Institute of Research and Empowerment.

Faisal, S. (1990). Penelitian Kualitatif: dasar-dasar dan aplikasi. Malang : YA3.

Handoko, T. H. (1996). Manajemen, edisi kedua. Yogyakarta: BPFE UGM.

Hartono, E. B. (2008). Pembangunan Partisipatif Masyarakat Desa Implementasinya dalam Program Alokasi Dana Desa", Tesis S-2 Sekolah Pascasarjana UNSOED Purwokerto (tidak dipublikasikan).

Haryanto, S. dan Arifuddin (2007). Akuntansi Sektor Publik, Edisi Pertama. Semarang : Universitas Diponegoro.

Hossein, B. (1997). Berbagai Faktor yang mempengaruhi Besarnya Otonomi Daerah Tingkat II, Suatu Kajian Desentralisasi dan Otonomi Daerah Dari Segi Ilmu Administrasi Negara (Desentralisasi), Jakarta.

Hudayana, B. dan Tim Peneliti FPPD. (2005). Peluang Pengembangan Partisipasi Masyarakat melalui Kebijakan Alokasi Dana Desa,Pengalaman Enam Kabupaten. Makalah disampaikan pada Pertemuan Forum Pengembangan Partisipasi Masyarakat (FPPM) di Lombok Barat 27-29 Januari 2005.

Indradi, S. S. (2010). Etika Birokrasi dan Akuntabilitas Sektor Publik. Malang : Agritek YPN Islamy (2003). Metodologi Penelitian Administrasi. Malang : Universitas Negeri Malang,.

Kaho, Y. R. (1997). Prospek Otonomi Daerah Di Negara Republik Indonesia. Jakarta : PT. Gravindo Persada.

Kecamatan Pesanggaran Dalam Angka 2016, Kerja sama BAPPEDA dan Badan Pusat Statistik Kabupaten Banyuwangi

Lembaga Administrasi Negara dan Badan Pengawasan Keuangan dan Pembangunan RI 2000, Akuntabilitas dan Good Governance, Modul 1-5, Modul Sosialisasi Sistem Akuntabilitas Kinerja Instansi Pemerintah (AKIP). Jakarta : LAN BPKP RI.

Lincoln, Y.S. \& Guba, E.G. (1985). Naturalistic Inquiry, $1^{\text {st }}$ edition. Beverly Hills: Sage Publication.

Machfud, S. (2002). Format Hubungan Keuangan Pemerintah Pusat dan Daerah yang Mengacu pada Pencapaian Tujuan Nasional. Seminar Nasional : Public Sector Score Card, Jakarta.

Mahmudi (2005). Manajemen Kinerja Sektor Publik. Yogyakarta : AMP YKPN.

Manulang (1991). Dasar - Dasar Manajemen. Jakarta : Ghalia Indonesia.

Mardiasmo (2002). Otonomi Daerah dan Manajemen Keuangan Daerah. Yogyakarta : Andi. 
Miles, H. S. (2014). Qualitatif Data Analysis. United State of America: Sage Publication Moeljarto (1995). Politik Pembangunan, Sebuah Analisis Konsep, Arah Dan Strategi. Yogjakarta : Tiara Wacana Yogya.

Moleong (2002). Metodologi Penelitian Kualitatif. Bandung : Remaja Rosdakarya. Nasution, S. 1996. Metode Penelitian Naturalistik. Bandung : Tarsito.

Ndraha, T. (2000). Ilmu Pemerintahan I \& II, BKU Ilmu Pemerintahan-IIP, Jakarta.

Nordiawan, D., Putra, I.S., dan Rahmawati, M. (2007). Akuntansi Pemerintahan. Jakarta : Salemba Empat.

Nugroho, R. (2003). Kebijakan Publik, Formulasi, Implementasi, dan Evaluasi. Jakarta: PT. Elek Media Komputindo, Kelompok Gramedia.

Peraturan Bupati Banyuwangi Nomor 15 tahun 2015 tentang pedoman pengelolaan keuangan desa di Kabupaten Banyuwangi.

Peraturan Bupati Banyuwangi Nomor 20 Tahun 2013 tentang Peraturan Pelaksanaan dan Pedoman Teknis Peraturan Daerah Kab. Banyuwangi Nomor 2 Tahun 2006 tentang ADD sebagaimana telah diubah dengan Peraturan Daerah Kabupaten Banyuwangi Nomor 2 Tahun 2007.

Peraturan Bupati Banyuwangi Nomor 20 Tahun 2013 tentang Petunjuk Pelaksanaan dan Pedoman Teknis Peraturan Daerah Kabupaten Banyuwangi Nomor 2 Tahun 2006 tentang Alokasi Dana Desa sebagaimana telah diubah dengan Peraturan Daerah kabupaten Banyuwangi Nomor 2 tahun 2007

Peraturan Pemerintah Nomor 72 Tahun 2005 tentang Desa.

Perda Kabupaten Banyuwangi Nomor 2 Tahun 2006 tentang ADD sebagaimana telah diubah dengan Perda Kabupaten Banyuwangi Nomor 2 Tahun 2007

Permendagri Nomor 35 Tahun 2007 tentang Pedoman Umum Tata Cara Pelaporan dan Pertanggungjawaban Penyelenggaraan Pemerintahan Desa

Permendagri Nomor 37 Tahun 2007 tentang Pedoman Pengelolaan Keuangan Desa

Ritzer, G. (1992). Sosiologi Ilmu Berparadigma Ganda. Jakarta : Rajawali Press.

Simanjutak, R. dan Hidayanto, D. (2002). Dana Alokasi Umum di MasaDepan dalam Sidik, Makhmud, Mahi, Raksaka, Simanjutak, Robert danBrodjonegoro, Bambang, 2002, Dana Alokasi Umum, Konsep, Hambatandan Prospek di Era Otonomi Daerah, LPEM FE UI, MPKP FE UI, DirjenPKPD, Kompas, Jakarta.

Stauss, A. \& Corbin, J. (2003). Basic of Qualitatif Research, Terjemahan Muhammad Shodiq dan Imam Muttaqien, Dasar-dasar Penelitian Kualitatif. Pustaka Pelajar.

Sugiyono (2011). Metode Penelitian Kuantitatif, Kualitatif dan R $\sim$ D. Bandung: Alfabeta.

Sujamto (1996). Aspek-aspek Pelaksanaan Otonomi Daerah. Jakarta : Bina Aksara.

Sulistiyani, A. T. (2004). Kemitraan dan Model-Model Pemberdayaan, Yogyakarta : GavaMedia. 
Sumarto, H. Sj. (2003). Inovasi, Partisipasi dan Good Governance, Bandung: Yayasan Obor Indonesia.

Sumaryadi, I Ny. (2016). Reformasi Birokrasi Pemerintahan menuju tatakelola pemerintahan yang baik. Bogor : Ghalia Indonesia.

Suparmoko (2002). Ekonomi Publik. Andi : Yogyakarta.

Suryono, A. (2010). Dimensi-dimensi Prima Teori Pembangunan. Malang: UBPress.

Susilo, A.A. (2006). "Formula Alokasi Dana Desa (ADD) di Kabupaten Kebumen, 2005”, Tesis S2 Sekolah Pascasarjana UGM (tidakdipublikasikan).

Susilo, B. (2007). “Ketimpangan Fiskal Antar Desa dan Formulasi Alokasi Dana Desa (ADD) di Kabupaten Magelang Tahun 2002 - 2007 ” Tesis S-2 Sekolah Pascasarjana UGM (tidakdipublikasikan).

Sutopo (2003). Metodologi Penelitian Kualitatif, Tinjauan Teoritis dan Praktis. Malang : LPUIM.

Undang-undang Nomor 33 Tahun 2004 tentang Perimbangan Keuangan antara Pemerintah Pusat dan Pemerintah Daerah.

Undang-Undang Nomor 6 Tahun 2014 tentang Desa. 